\title{
Distribution of albacore (Thunnus alalunga) in the Indian Ocean and its relation to environmental factors
}

\author{
I-CHING CHEN, PEI-FEN LEE,* AND \\ WANN-NIAN TZENG \\ Department of Zoology, National Taiwan University, Taipei \\ 106, Taiwan
}

\begin{abstract}
The distribution pattern of albacore, Thunnus alalunga, in the Indian Ocean was analyzed based on catch data from the Taiwanese tuna longline fishery during the period 1979-85. The Taiwanese tuna fishery began operating in the Indian Ocean in 1967. We used a geographic information system to compile a fishery and environmental database and statistically explored the catch per unit effort (CPUE) distribution of albacore. Our results indicated that immature albacore were mainly distributed in areas south of $30^{\circ} \mathrm{S}$ although some displayed a north-south seasonal migration. Mature albacore, which were mainly concentrated between $10^{\circ} \mathrm{S}$ and $25^{\circ} \mathrm{S}$, also showed a north-south migration. Within $10^{\circ} \mathrm{S}$ and $30^{\circ} \mathrm{S}$, the separation of mature, spawning, and immature albacore life history stages roughly coincided with the boundaries of the three oceanic current systems in the Indian Ocean. The optimal environmental variables for CPUE prediction by stepwise discriminant analysis differed among life history stages. For immature albacore, the sea surface variables sea surface temperature (SST), chlorophyll concentration and surface salinity were significant. For mature albacore, SST was significant, while for spawning albacore, the sub-surface variables temperature at $100 \mathrm{~m}$ and oxygen at $200 \mathrm{~m}$ were significant. Spawning
\end{abstract}

*Correspondence. e-mail: leepf@ntu.edu.tw

Present addresses: Pei-Fen Lee, Institute of Ecology and Evolutionary Biology, National Taiwan University, Taipei 106, Taiwan.

Wann-Nian Tzeng, Institute of Fisheries Sciences, National Taiwan University, Taipei 106, Taiwan.

Received 8 May 2003

Revised version accepted 30 March 2004

(C) 2005 Blackwell Publishing Ltd. albacore evidently prefer deep oceanographic conditions. Our results on the oceanographic conditions preferred by different developmental stages of albacore in the Indian Ocean were compatible with previous studies found in the Pacific Ocean.

Key words: albacore, current systems, distribution, environmental factors, Indian Ocean, life history stage

\section{INTRODUCTION}

Albacore (Thunnus alalunga) is one of the main target species of the commercial tuna fishery and has a long history of scientific research. The species is highly migratory and widely distributed in the three major oceans from $50^{\circ} \mathrm{N}$ to $40^{\circ} \mathrm{S}$, with the exception of $25^{\circ} \mathrm{N}$ in the Indian Ocean (Collette and Nauen, 1983). Our understanding of this species, however, comes mostly from studies in the Pacific Ocean. Albacore in the Indian Ocean have, for the last four decades, been mainly exploited by Taiwan, Japan, and Korea. Most studies of this species have examined stock discrimination, age determination, and production models (Hsu, 1994) while research about distribution and fishery oceanography has been sparse relative to its long history of exploitation.

The distribution of albacore in the Pacific Ocean and its relation to oceanic structure has been widely discussed (Clemens, 1961; Laurs and Lynn, 1977; Kimura et al., 1997). In the North Pacific Ocean, the size composition of albacore differed among three current areas. Immature albacore inhabit subtropical waters lying between $25^{\circ} \mathrm{N}$ and $35^{\circ} \mathrm{N}$ and are dominant in the area of the North Pacific Current. Mature albacore are distributed in the North Equatorial Current and Equatorial Counter Current areas while spawning albacore are concentrated at about $20^{\circ} \mathrm{N}$. The distribution of albacore in the South Pacific Ocean was roughly symmetrical with that in the North Pacific Ocean (Nakamura, 1969). A discontinuity layer that occurs about $10^{\circ} \mathrm{S}$, supported by a vertical distribution of temperature and salinity, is the northern limit of the main fishing grounds (Yamanaka, 1956). Size frequencies of albacore indicate that mature and immature albacore were roughly separated 
by $30^{\circ} \mathrm{S}$ while spawning areas occurred between $10^{\circ} \mathrm{S}$ and $25^{\circ} \mathrm{S}$ (Ueyanagi, 1969).

The Indian Ocean albacore is considered to be a unit stock and its size composition varies with latitude (Hsu, 1994). Generally, mature albacore are concentrated in the equatorial areas, immature albacore are distributed in the higher latitudes, and the main spawning area occurs in the waters off eastern Madagascar (Koto, 1969; Shiohama, 1985). Suda (1974) suggested that there is a boundary at about $30^{\circ} \mathrm{S}$ between albacore age groups, with spawning albacore in the waters north of it and immature albacore, mainly 3-5 yr old, concentrating further south. Hsu (1994) classified the Indian Ocean albacore by latitude, with the mature group northward of $10^{\circ} \mathrm{S}$, the spawning group between $10^{\circ} \mathrm{S}$ and $30^{\circ} \mathrm{S}$, and the immature group southward of $30^{\circ} \mathrm{S}$. This conclusion was based on size segregation from measured length frequency data, which was accurate but spanned a limited time and geographic area. Data from the Taiwanese longline fishery, which has extended for several decades and throughout the whole Indian Ocean, are analyzed here and compared with previous research.

Previous studies have indicated that the distribution of albacore is affected by sea surface temperature (SST) (Sund et al., 1981; Ramos et al., 1996), hydographic fronts (Laurs and Lynn, 1977; Laurs et al., 1984; Fiedler and Bernard, 1987; Stretta, 1991; Kimura et al., 1997), and depth of the thermocline (Ueyanagi, 1969). These studies mostly occurred in the Pacific Ocean, used overall catch per unit effort (CUPE) as the fishing index, and temperature as the predictive index. The Indian Ocean formed a gap in our understanding of the fishery oceanography of albacore. For a highly migratory species with size segregation by geographic zone, it is reasonable to expect different preferences for environmental conditions for each life history stage and CPUE should be discussed respectively. In previous studies, SST was discussed for its importance and availability. However, the albacore can be a deep swimmer, highly mobile, and has special oxygen requirements (Yoneta and Saito, 1973; Collette and Nauen, 1983). The adaptation of this species to three dimensions, particularly depth, must be considered for a better explanation of their geographic distribution.

The limitations of past studies of fishery oceanography in concurrent fishery data and environmental information across temporal and spatial scales have been overcome by the improvement of remote sensing and geographic information systems. We used sea surface data throughout the whole Indian Ocean from satellite images and sub-surface data collected by vessel sampling as well as the major fishery database, in a comprehensive study of the environmental preferences of three life history stages of Indian Ocean albacore.

\section{METHODS}

\section{Fishery data}

The Taiwanese longline fishery, extending throughout the Indian Ocean, catches $60-90 \%$ of the annual production of albacore in Indian Ocean (Hsu, 1994). The Oversea Fisheries Development Council (OFDC) in Taiwan has compiled data on the Taiwanese longline fishery for the period of 1967 and 1997. The catch data, including monthly summaries of total hook numbers, and the catch numbers and total weights of three dominant tuna species, albacore, bigeye tuna (T. obesus) and yellowfin tuna ( $T$. albacares), were georeferenced in $5^{\circ}$ grids of latitude and longitude.

\section{Environmental data}

The environmental data were collected from NASA's web sites and the National Oceanographic Data Center-Ocean Climate Laboratory (NODC/OCL). SST from 1967 to 1994 and chlorophyll concentration index from 1978 to 1986 were obtained from the Advanced Very High Resolution Radiometer (AVHRR) carried aboard the NOAA-series polar-orbiting satellites and the Nimbus-7 Coastal Zone Color Scanner (CZCS), respectively. Subsurface data, including temperature, salinity, and dissolved oxygen to a depth of nearly $4000 \mathrm{~m}$, were obtained from the World Ocean Database 1998 (WOD98, http://www.nodc.noaa.gov/ OC5/pr_wodv2.html) issued from NODC/OCL. For comparison with the fishing data, all oceanographic variables were converted into monthly $-5^{\circ}$ means for each of three levels (0, 100 and $200 \mathrm{~m})$ (Table 1).

\section{Data analysis}

Extracting the fishing effort directed towards albacore is essential to evaluating the abundance index (Wang et al., 2001). During the fishery history, there have been changes in targeted species and fishing methods. Taiwanese longline vessels spread to the whole Indian Ocean after 1973 and adopted 'conventional longlining' targeting albacore. 'Deep longlining' was introduced to the Indian Ocean during the 1980s and targeted bigeye tuna and yellowfin tuna. Wang et al. (2001) used a fuzzy synthesis approach to separate the fishing effort. In our paper, we followed their method. 
Table 1. Environmental variables selected in this study.

\begin{tabular}{|c|c|c|c|}
\hline Variables & Code & Resolution & Annotation \\
\hline $\begin{array}{l}\text { Chlorophyll } \\
\text { concentration } \\
\left(\mathrm{mg} \mathrm{m}^{-3}\right)\end{array}$ & CZM & Monthly $5^{\circ}$ grids & $\begin{array}{l}\text { Mean value of } \\
\text { chlorophyll } \\
\text { concentration }\end{array}$ \\
\hline Temperature $\left({ }^{\circ} \mathrm{C}\right)$ & $\begin{array}{l}\text { SST } \\
\text { TEMP_100 } \\
\text { TEMP_200 }\end{array}$ & Monthly $5^{\circ}$ grids & $\begin{array}{l}\text { Temperature at the } \\
\text { surface, } 100 \text { and } \\
200 \mathrm{~m} \text { depth }\end{array}$ \\
\hline Salinity (psu) & $\begin{array}{l}\text { SAL_0 } \\
\text { SAL_100 } \\
\text { SAL_200 }\end{array}$ & Seasonal $5^{\circ}$ grids & $\begin{array}{l}\text { Salinity at the surface, } \\
100 \text { and } 200 \mathrm{~m} \text { depth }\end{array}$ \\
\hline $\begin{array}{l}\text { Dissolved oxygen } \\
\left(\mathrm{mg} \mathrm{L}^{-1}\right)\end{array}$ & $\begin{array}{l}\text { OXY_0 } \\
\text { OXY_100 } \\
\text { OXY_200 }\end{array}$ & Seasonal $5^{\circ}$ grids & $\begin{array}{l}\text { Oxygen at the surface, } \\
100 \text { and } 200 \mathrm{~m} \text { depth }\end{array}$ \\
\hline
\end{tabular}

Despite the fact that our database consists of various time spans, our analyses only selected the data from 1979 to 1985 because this period corresponds to the high availability and quality of the CZCS data, and albacore was the major target species of the Taiwanese longline vessels (Wang, 2001). The areas from $30^{\circ} \mathrm{N}$ to $50^{\circ} \mathrm{S}$ latitude and from $25^{\circ} \mathrm{E}$ to $125^{\circ} \mathrm{E}$ longitude were included. We used a geographical information system to construct a database of the fishery and environmental data sets. Statistical analyses were performed using SAS (Research Triangle Park, North Carolina, USA).

\section{Distribution patterns}

For each record, CPUE (catch number per 100 hooks) and average weight (total weight/total number) were calculated. An initial display of monthly CPUEs for the $7 \mathrm{yr}$ showed minor yearly variations. Some of the monthly data sets were not large enough to allow for a good pattern because of inadequate samples. We then combined the data in a specific month within the study period to map the distribution of CPUE and average weight distribution.

The length at first maturity of Indian Ocean albacore (90 cm; Ueyanagi, 1969; Wu and Kuo, 1993) was substituted into the von Bertalanffy growth equation by Huang et al. (1990):

$$
\begin{gathered}
L_{t}=128.127\left[1-e^{-0.162(t+0.897)}\right] \\
W_{t}=36.831\left[1-e^{-0.162(t+0.897)}\right]^{2.857}
\end{gathered}
$$

and by Lee and Liu (1992):

$$
\begin{gathered}
L_{t}=163.71\left[1-e^{-0.1019(t+2.0668)}\right] \\
W_{t}=81.7\left[1-e^{-0.1019(t+2.0668)}\right]^{2.8758}
\end{gathered}
$$

where $L t$ is the length (in $\mathrm{cm}$ ) at specific time $t$ and $W_{t}$ is the weight (in $\mathrm{kg}$ ) at a specific $t$.
Thus, the predicted weight at first maturity of $90 \mathrm{~cm}$ in length was estimated as 13.462 and $14.622 \mathrm{~kg}$, respectively. We took $14 \mathrm{~kg}$ as a threshold to separate mature and immature albacore for each catch record. Monthly CPUE distributions of mature and immature albacore were mapped to understand their seasonal movement patterns. SST maps were overlaid to illustrate movement patterns in relation to sea surface conditions.

Hsu (1994) noted that distribution of albacore in the Indian Ocean could be classified by latitude, i.e. mature fish stay in waters north of $10^{\circ} \mathrm{S}$, spawning ones stay between $10^{\circ} \mathrm{S}$ and $30^{\circ} \mathrm{S}$, and immature ones stay south of $30^{\circ} \mathrm{S}$. We defined three regions separated by the $10^{\circ} \mathrm{S}$ and $30^{\circ} \mathrm{S}$ and computed the average weight composition in each region. Two periods, corresponding to spawning (October to March) and nonspawning (April to September) seasons, were also examined.

\section{Predicting CPUE by environmental factors}

Discriminant analysis is commonly used for classification but it is also useful for discriminating among groups. We identified CPUE data as three categories which represent different life history stages of albacore tuna: immature (average weight $<14 \mathrm{~kg}$ ), spawners (average weight $>14 \mathrm{~kg}$ recorded between $10^{\circ} \mathrm{S}$ and $30^{\circ} \mathrm{S}$ during October to March), and non-spawning mature fish (mature albacore other than spawners). For each life history category, the CPUE means were divided into two levels, higher (level 1) and lower (level 2); i.e. CPUE records higher than mean value were classified as level 1 and the lower ones as level 2. The CPUE for each life history category, in relation to environmental factors, was predicted by stepwise discriminant analysis (SDA). Total error rates for these variables were then evaluated by discriminant function analysis. 


\section{RESULTS}

\section{Distribution patterns}

Albacore were distributed throughout the Indian Ocean between $25^{\circ} \mathrm{N}$ and $45^{\circ} \mathrm{S}$. Areas of high CPUE occurred between $25^{\circ}$ and $45^{\circ} \mathrm{S}$ and, to a small extent, in the western Arabian Sea (Fig. 1). By-catch occurred in the Bay of Bengal and most of the equatorial areas north of $10^{\circ} \mathrm{S}$.

The average weight distribution indicated that albacore larger than $14 \mathrm{~kg}$ congregated in the central Indian Ocean and albacore smaller than $14 \mathrm{~kg}$ concentrated south of $30^{\circ} \mathrm{S}$ (Fig. 2). The highest albacore CPUEs of the Taiwanese longline fishery largely consisted of fish less than $14 \mathrm{~kg}$.

Immature albacore were mainly distributed south of $30^{\circ} \mathrm{S}$ in May (Fig. 3). They moved north to $25^{\circ} \mathrm{S}$ in August, then to the area between $15^{\circ} \mathrm{S}$ and $25^{\circ} \mathrm{S}$ in November, and gradually returned to the southern part of their distribution in February.
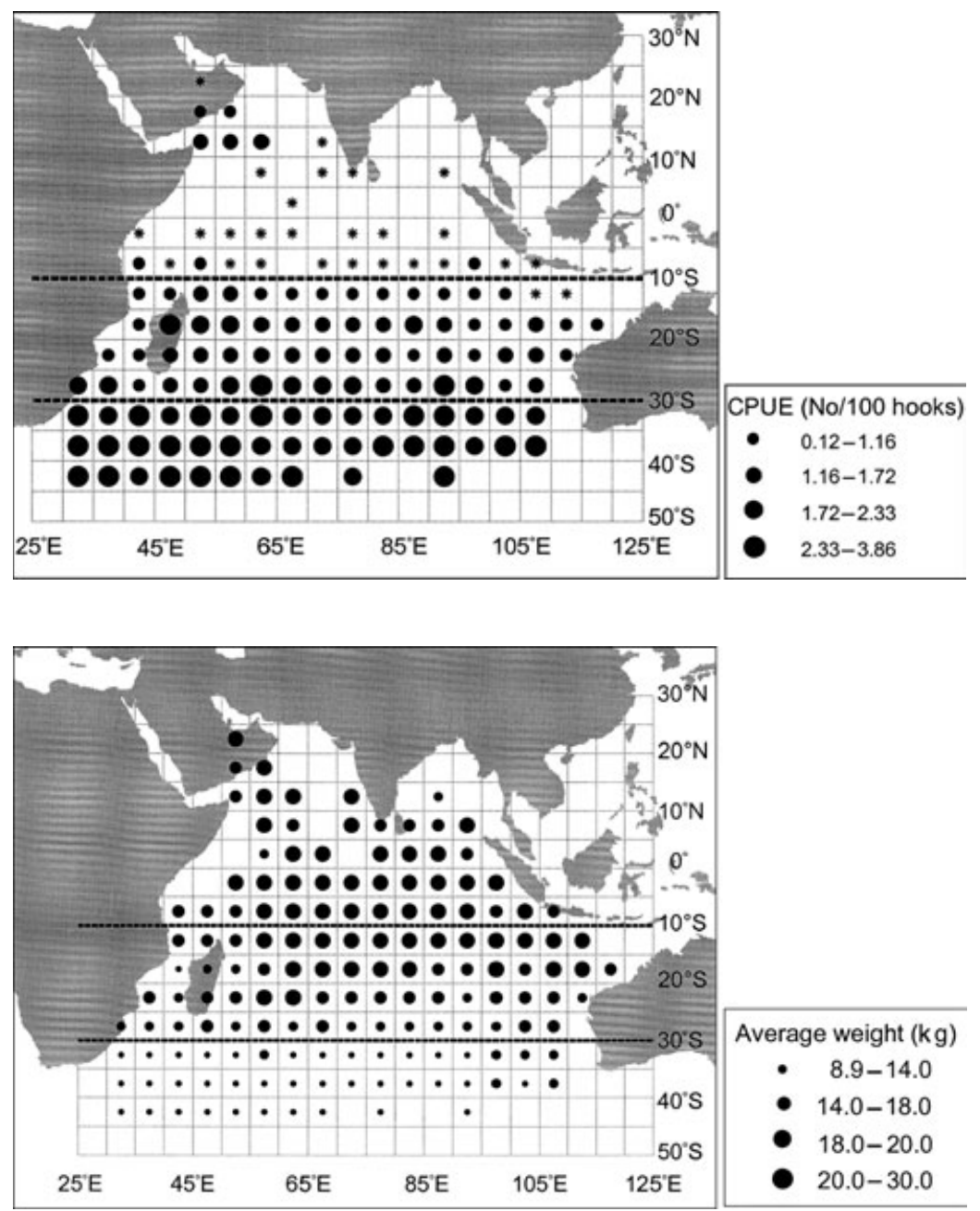

Average weight $(\mathrm{kg})$

- $8.9-14.0$

- $14.0-18.0$

- $18.0-20.0$

$20.0-30.0$
Figure 1. The distribution of Taiwanese albacore longline fishery CPUE in the Indian Ocean (mean value of 1979-85). Circle size represents quantiles of CPUE and ' $*$ ' indicates the places where albacore were recorded as by catch.
Figure 2. The distribution of albacore average weights from the Taiwanese longline fishery in the Indian Ocean (mean value of 1979-85). 
Figure 3. The distribution of Taiwanese longline fishery CPUE for immature albacore in the Indian Ocean (mean value of 1979-85). Circle sizes represent quantiles of each month and '*' represents the places immature albacore mostly recorded as by catch.
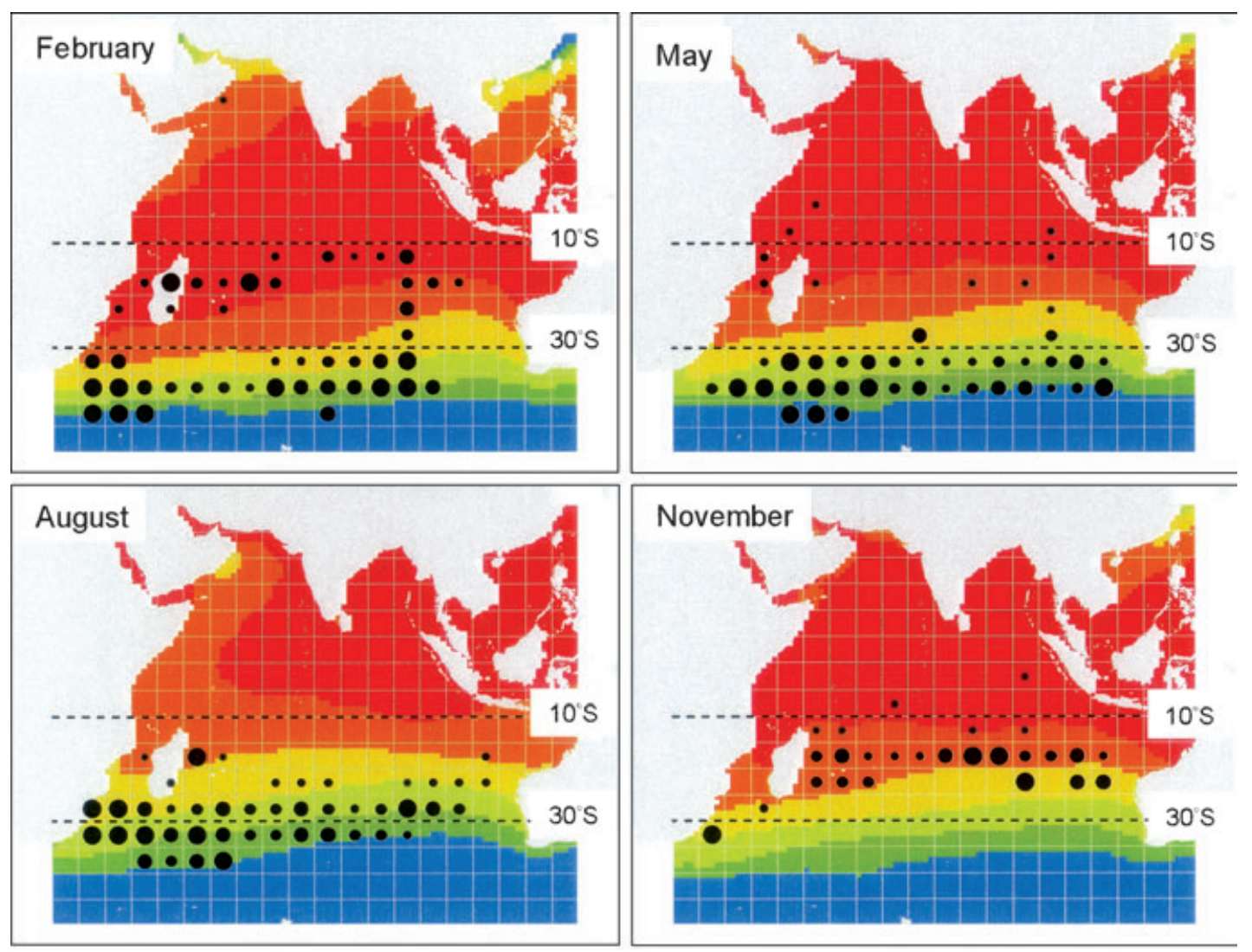

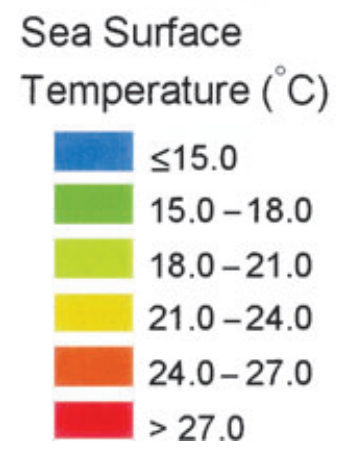

occur in region II during the non-spawning season. Many albacore in region III, south of $30^{\circ} \mathrm{S}$, are immature, with a mean weight of nearly $13 \mathrm{~kg}$ throughout the year.

\section{Environmental indices}

The environmental variables selected by the SDA differed among life stages (Table 2). For immature albacore, the largest partial $R^{2}$ was because of SST, followed by chlorophyll concentration and surface salinity. The average SST in the high CPUE zone

\section{CPUE quantile \\ - $\leq$ Q1 \\ - Q1-Q2 \\ - Q2-Q3 \\ - > Q3}

(level 1) was $18.9^{\circ} \mathrm{C}$, which is much lower than the $24.1^{\circ} \mathrm{C}$ in the low CPUE zone (level 2). The mean values of chlorophyll concentration and salinity were higher in CPUE level 1 than in level $2\left(0.17 \mathrm{mg} \mathrm{m}^{-3}\right.$ and $35.32 \mathrm{psu}$ versus $0.09 \mathrm{mg} \mathrm{m}^{-3}$ and $34.89 \mathrm{psu}$ ). The predicting error rate was lower than 20\% (Table 3).

For mature albacore, the environmental variables most correlated with CPUE prediction differed between non-spawning and spawning stages (Table 2). Only SST was significant for the non-spawning stage 
Figure 4. CPUE distribution of mature albacore in the Indian Ocean (mean value of 1979-85 Taiwanese long-line fishery data). Circle size identified by quantiles of CPUE, by month, and '*' the places where mature albacore were recorded as by-catch.
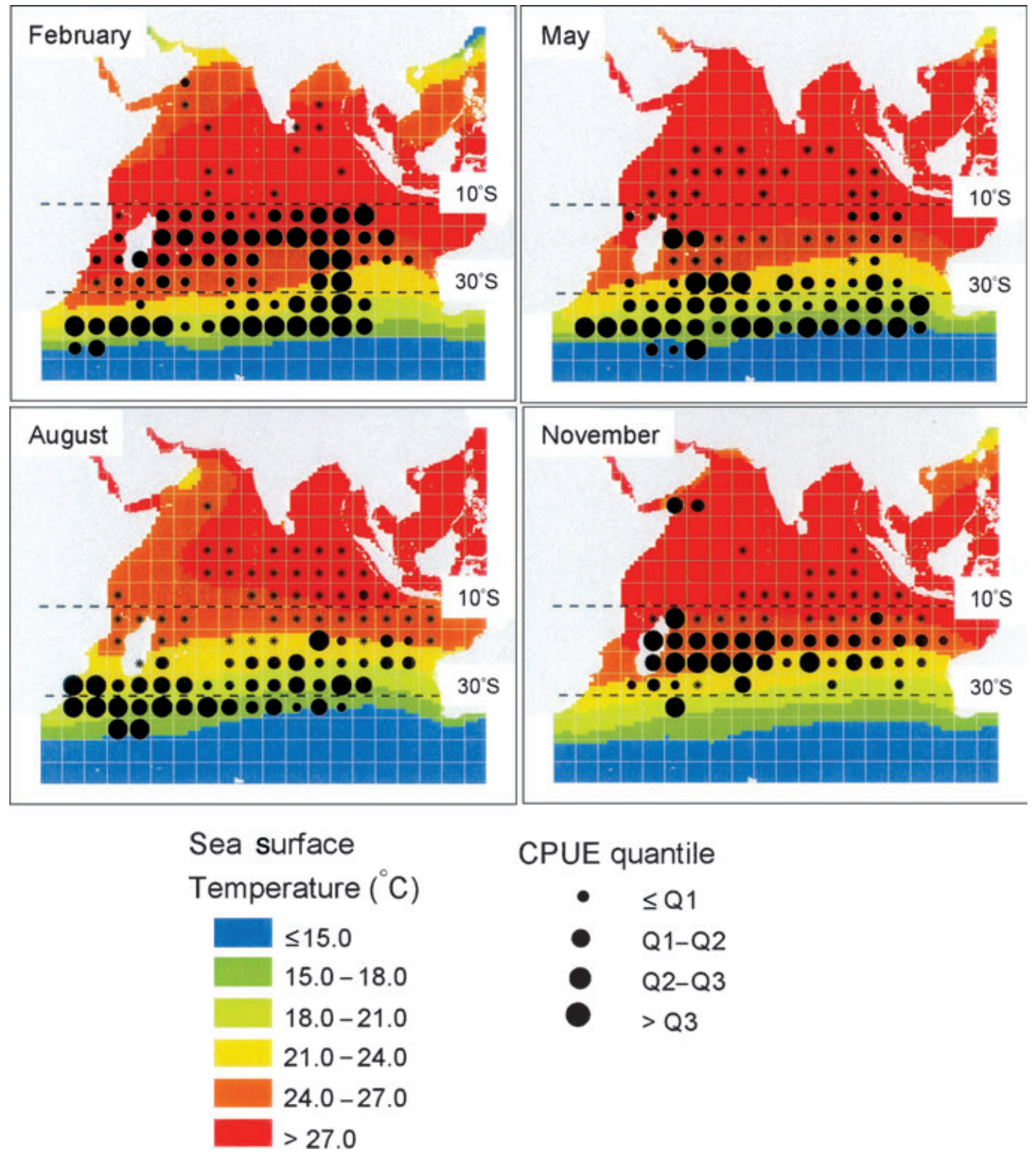

but four variables were useful for spawning stage: SST, TEMP_100 (temperature at $100 \mathrm{~m}$ depth), surface salinity and OXY_200 (dissolved oxygen at $200 \mathrm{~m}$ depth). The average SST for non-spawning mature albacore was also much lower in CPUE level 1 than in level $2\left(19.1^{\circ} \mathrm{C}\right.$ versus $\left.21.7^{\circ} \mathrm{C}\right)$. Although the differences between SST values for spawning albacore between CPUE levels were smaller $\left(24.9^{\circ} \mathrm{C}\right.$ and $\left.25.7^{\circ} \mathrm{C}\right)$ than for non-spawners, they were higher in absolute value. The other three discriminant variables selected

for spawning albacore did not differ between CPUE levels. The prediction error rate for each spawning stage was 34 and $35 \%$, respectively (Table 3 ).

\section{DISCUSSION}

The hypothesis of distribution pattern

Distribution patterns of the albacore in the Indian Ocean are similar to those found in the Pacific (Clemens, 1961; Laurs and Lynn, 1977; Kimura et al., 
Figure 5. The average weight composition of albacore from the Taiwanese longline fishery in the Indian Ocean (1979$85)$ by spawning season (October to March) and nonspawning season (April to September), for each of three geographic regions (region 1: north of $10^{\circ} \mathrm{S}$; region 2: between $10^{\circ} \mathrm{S}$ and $30^{\circ} \mathrm{S}$; region 3: south of $30^{\circ} \mathrm{S}$ ).

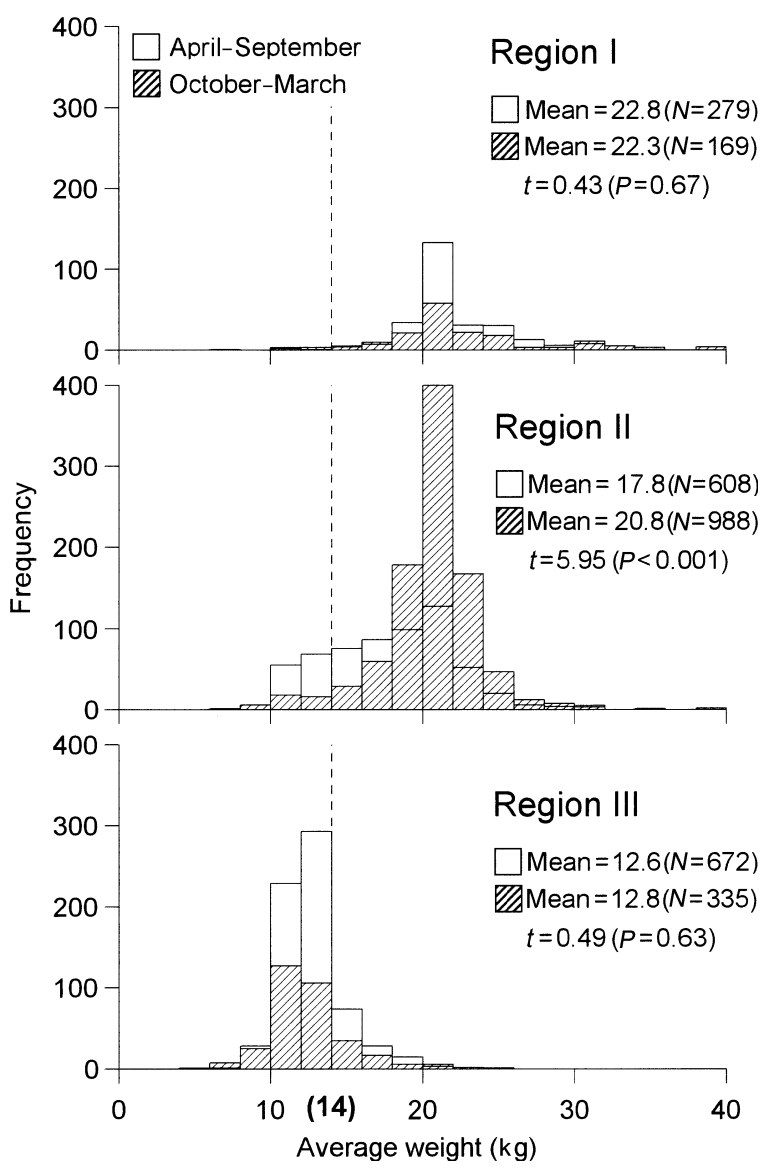

1997). The albacore migrates over great distances and appears to form separate groups at different stages of its life cycle. The movement of immature and mature albacore across $30^{\circ} \mathrm{S}$ resulted in a significant difference in their size composition between spawning and nonspawning seasons. Immature albacore were mainly distributed in areas south of $30^{\circ} \mathrm{S}$ although some displayed a north-south seasonal migration. Mature albacore, mainly concentrated between $10^{\circ} \mathrm{S}$ and $30^{\circ} \mathrm{S}$, also showed a seasonal migration pattern.

The latitudes of $10^{\circ} \mathrm{S}$ and $30^{\circ} \mathrm{S}$ separate mature, spawning, and immature albacore life history stages. They roughly coincided with the boundaries of the three oceanic current systems in the Indian Ocean. The regions correspond to the boundaries of three major current systems in the Indian Ocean: (1) north of $10^{\circ} \mathrm{S}$ the monsoon-driven current prevails, (2) between $10^{\circ} \mathrm{S}$ and $30^{\circ} \mathrm{S}$ the subtropical gyre occurs, and (3) south of $30^{\circ} \mathrm{S}$ the Circumpolar Current occurs (Wyrtki, 1973). This indicates that the size segregation of the albacore was virtually parallel with the oceanic current systems in the Indian Ocean. Changes in currents are evidenced by measurements of physical factors such as temperature, salinity, nutrients, and sea level, and correlated to distribution and abundance of dependent organisms such as phytoplankton, invertebrates, and fish.

The coincidence of size segregation and oceanic current systems generally agrees with the migration hypothesis of the Pacific albacore, as suggested by Nakamura (1969), in which the widely distributed tuna species usually migrated across the current systems during changes in developmental stage. The effect of currents on the distribution of tuna should, indirectly, result from the thermocline topography,
Table 2. Environmental variables in relation to albacore longline fishery CPUE for each life history stage using stepwise discriminant analysis.

\begin{tabular}{|c|c|c|c|c|c|c|}
\hline \multirow{2}{*}{$\begin{array}{l}\text { Life history } \\
\text { stages }\end{array}$} & \multirow[b]{2}{*}{ Step } & \multirow[b]{2}{*}{ Variables } & \multicolumn{2}{|c|}{$\begin{array}{l}\text { Means of varia- } \\
\text { bles in CPUE }\end{array}$} & \multirow[b]{2}{*}{ Partial $R^{2}$} & \multirow{2}{*}{$\begin{array}{l}\text { Wilks' } \\
\text { lambda }\end{array}$} \\
\hline & & & Level 1 & Level 2 & & \\
\hline \multirow{3}{*}{ Immature } & 1 & SST & 18.9 & 24.1 & 0.341 & $0.66 * * *$ \\
\hline & 2 & CZM & 0.17 & 0.09 & 0.040 & $0.63 * * *$ \\
\hline & 3 & SAL_O & 35.32 & 34.89 & 0.015 & $0.62 * * *$ \\
\hline $\begin{array}{l}\text { Mature } \\
\text { (non-spawning) }\end{array}$ & 1 & SST & 19.1 & 21.7 & 0.132 & $0.87 * * *$ \\
\hline Mature & 1 & SST & 24.9 & 25.7 & 0.034 & $0.97 *$ \\
\hline \multirow[t]{3}{*}{ (spawning) } & 2 & TEMP_100 & 21.3 & 21.1 & 0.039 & $0.93 * *$ \\
\hline & 3 & SAL_0 & 35.01 & 34.86 & 0.023 & $0.91 * * *$ \\
\hline & 4 & OXY_200 & 5.75 & 5.09 & 0.030 & $0.88 * * *$ \\
\hline
\end{tabular}

CPUE records higher than mean value were classified as level 1 and the lower ones as level 2 .

$$
* P<0.05 ; * * P<0.01 ; * * * P<0.001 \text {. }
$$


Table 3. Prediction of albacore longline fishery CPUE by environmental variables using discriminant function analysis.

\begin{tabular}{|c|c|c|c|c|}
\hline \multirow{2}{*}{$\begin{array}{l}\text { Life history stages } \\
\text { and CPUE }\end{array}$} & \multicolumn{3}{|c|}{ Predicted class } & \multirow{2}{*}{$\begin{array}{l}\text { Error } \\
\text { rate }(\%\end{array}$} \\
\hline & Level 1 & Level 2 & Total & \\
\hline \multicolumn{5}{|l|}{ Immature albacore } \\
\hline Level 1 & $205(82.3)^{*}$ & $44(17.7)$ & 249 & 20 \\
\hline Level 2 & $55(21.4)$ & $202(78.6)$ & 257 & \\
\hline \multicolumn{5}{|l|}{$\begin{array}{l}\text { Mature albacore } \\
\text { (non-spawning) }\end{array}$} \\
\hline Level 1 & $134(68.7)$ & $61(31.3)$ & 195 & 34 \\
\hline Level 2 & $70(36.1)$ & $124(63.9)$ & 194 & \\
\hline \multicolumn{5}{|l|}{$\begin{array}{l}\text { Mature albacore } \\
\text { (spawning) }\end{array}$} \\
\hline Level 1 & $53(63.1)$ & $31(36.9)$ & 84 & 35 \\
\hline Level 2 & $32(33.3)$ & $64(66.7)$ & 96 & \\
\hline
\end{tabular}

CPUE records higher than mean value were classified as level 1 and the lower ones as level 2 .

* Number of observations (percentage).

temperature, or prey distribution unique to those currents (Sund et al., 1981).

\section{Environmental preferences}

The variable discrimination process in the CPUE prediction model implied statistical correlation rather than causal result; thus, only the relations among environmental factors and distribution patterns can be given. However, these relations suggest potential insight into the environmental preferences in each life history stage of the albacore.

Rather high variability in the CPUE prediction exists using discriminant function analysis. This discrimination accuracy was less precise in the mature stage. We suspect this was due to the fact that the tuna catch data were recorded in coarse resolution; at this scale these data may not provide necessary information to explore finer detail and, thus, create higher variability in the CPUE prediction in our models. In addition, our aggregation of $7 \mathrm{yrs}$ catch data may create a new source of noise because the effects of El Niño were ignored in our analysis. ENSO events are characterized by unusually warm water temperatures, disruption of nearshore upwelling, and subsequent decreases in primary and secondary production. As a result, northward catch of albacore was apparent during ENSO events (Chen, 2000).

The best sets of environmental variables for CPUE prediction of immature or non-spawning albacore in a multivariable analysis were all surface factors, i.e. SST, chlorophyll concentration, and surface salinity. In contrast, sub-surface variables, such as temperature at $100 \mathrm{~m}$ depth and dissolved oxygen at $200 \mathrm{~m}$, were also selected in spawning albacore. These differences may reflect the physiological requirements in different life history stages.

In all three life stages, SST was clearly an important predictor of CPUE in the albacore longline fishery. View on an ocean scale, SST represented not only the temperature but also the correspondence with latitudes. It is expected to find the significance of SST when the distribution is geographically specific. Studies in the Pacific Ocean have generally shown that the lower and upper limits of SST suitable for albacore were $14^{\circ} \mathrm{C}$ and $23^{\circ} \mathrm{C}$ while high CPUE records occurred between $14^{\circ} \mathrm{C}$ and $21^{\circ} \mathrm{C}$ (Laurs and Lynn, 1977). The Indian Ocean is different in that albacore, both mature and immature, were found even where the SST was higher than $27^{\circ} \mathrm{C}$. The corresponding limits of SST at high albacore abundance depended on life stage and season. For immature albacore, areas with SST between $15^{\circ} \mathrm{C}$ and $21^{\circ} \mathrm{C}$ had higher CPUEs, except during November (Fig. 3). For mature albacore, the lower limit of SST for high CPUE was also $15^{\circ} \mathrm{C}$, but the upper limit changed with time (Fig. 4). Most mature albacore were distributed in waters above $27^{\circ} \mathrm{C}$ in February. Although albacore in the Indian Ocean occurred over a wide range of SST, the equatorial area with a high SST throughout the year was largely unsuitable habitat where albacores occur mostly as by-catch.

For immature albacore, high CPUE records correspond with higher values of chlorophyll concentration. Areas south of $30^{\circ} \mathrm{S}$ in the Indian Ocean, where the immature albacore gather, exhibited high chlorophyll concentration by the satellite images (Chen, 2000). Studies have shown that water color is an index of higher primary production, which may attract aggregations of fish. This may be especially true for feeding schools of immature albacore. Laurs et al. (1984) indicated the importance of phytoplankton pigment concentration in explaining albacore distribution. In contrast, coastal areas of Arabian Sea, another region with high chlorophyll concentration, should lack high CPUE due to the SST limitation. Data from WOD 98 showed an uneven pattern of salinity distribution in the Indian Ocean (Chen, 2000). Surface current system was the cause of low salinity bands in the areas between $10^{\circ} \mathrm{S}$ and $20^{\circ} \mathrm{S}$, and southward of $40^{\circ} \mathrm{S}$. Concentration of immature albacore matched the higher salinity zones, yet we could not conclude from our observations whether the current system or the salinity itself caused the coincidence. 
Sub-surface variables, such as temperature at $100 \mathrm{~m}$ depth and dissolved oxygen at $200 \mathrm{~m}$, were selected in the CPUE prediction of spawning albacore. Pre-spawning tunas are highly migratory in search of a suitable habitat for their larvae and may stay in waters that are poor habitats for adults. Saito et al. (1970) found that, in areas between $15^{\circ} \mathrm{S}$ and $20^{\circ} \mathrm{S}$ latitude during October and December, the hooking rate of the vertical longline fishery was highest at a depth of $200-300 \mathrm{~m}$ and remained high at $380 \mathrm{~m}$. Deep oceanic conditions would be essential. Ueyanagi (1969) suggested that the oceanographic characteristics of the spawning areas might have a SST of at least $24^{\circ} \mathrm{C}$, with a deep mixed layer and no thermocline existing to about $250 \mathrm{~m}$. This implied a higher temperature in sub-surface water to the depth, supported by our study, indicating a high temperature of $21^{\circ} \mathrm{C}$ at $100 \mathrm{~m}$ deep.

Sund et al. (1981) concluded that only temperature is related to tuna spawning and larval survival, and zooplankton abundance and salinity have not been conclusively shown to be influential. Our results suggested temperature, salinity and dissolved oxygen be the predictors of spawners CPUE, but the differences of environmental variables between two CPUE levels were too weak to give further support due to the coarse resolution in our data set. More information concerning albacore biology is needed.

In conclusion, our study of the fishery oceanography of albacore in the Indian Ocean provided a comparison with that of the Pacific. Despite some minor differences, our results on the oceanographic conditions preferred by different developmental stages of albacore in the Indian Ocean were generally consistent with studies conducted in the Pacific. The oceanographic variables most useful for the spatial prediction of CPUE by the albacore longline fishery varied among life stages. Management policy for albacore requires an understanding of distribution pattern. This knowledge is important for the sustainable use of this unique natural resource.

\section{ACKNOWLEDGEMENTS}

We are grateful to the Oversea Fisheries Development Council of the Republic of China for providing the long-term longline fishery data, and to Drs C.K. Chang and H.J. Hsu for data manipulation, and to B.M. Jessop for editorial review of the manuscript. We also thank two anonymous reviewers for their helpful comments and suggestions. This study was funded by Fisheries Administration, Council of Agriculture and National Science Council, Taiwan.

\section{REFERENCES}

Chen, I.C. (2000) Fishing ground of the Indian Ocean albacore (Thunnus alalunga) and its relationship with environmental factors. Master Thesis, National Taiwan University (in Chinese, English summary).

Clemens, H.B. (1961) The migration, age, and growth of Pacific albacore (Thunnus germo), 1951-1958. Calif. Dept. Fish Game, Fish Bull. 115:128.

Collette, B.B. and Nauen, C.E. (1983) FAO species catalogue. Vol. 2. Scombrids of the world. An annotated and illustrated catalogue of tunas, mackerels, bonitos, and related species known to date. FAO Fisheries Synopsis No. 125, Vol. 2. Rome, Italy: FAO Press, 137 pp.

Fiedler, P.C. and Bernard, H.J. (1987) Tuna aggregation and feeding near fronts observed from satellite imagery. Cont. Shelf. Res. 7:871-881.

Hsu, C.C. (1994) The status of Indian Ocean albacore - A review of previous work. Proceedings of the Fifth Expert Consult on Indian Ocean Tunas. Indo-Pacific Tuna Development and Management Programme. Coll. Vol. Work. Doc. 8:117-124.

Huang, C.S., Wu, C.L., Kuo, C.L. and Su, W.C. (1990) Age and growth of the Indian Ocean albacore, Thunnus alalunga, by scales. FAO IPTP/TWS/90/53 111-122.

Kimura, S., Nakai, M. and Sugimoto, T. (1997) Migration of albacore, Thunnus alalunga, in the North Pacific Ocean in relation to large oceanic phenomena. Fish. Oceanogr. 6:51-57.

Koto, T. (1969) Studies on the albacore-XIV. Distribution and movement of the albacore in the Indian and the Atlantic Oceans based on the catch statistics of Japanese tuna longline fishery. Bull. Far Seas Fish. Res. Lab. 1:115-129.

Laurs, R.M. and Lynn, R.J. (1977) Seasonal migration of North Pacific albacore, Thunnus alalunga, into North America coastal waters: distribution, relative abundance and association with transition zone waters. US Fish. Bull. 75:795-822.

Laurs, R.M., Fiedler, P.C. and Montgomery, D.R. (1984) Albacore tuna Thunnus alalunga catch distribution relative to environment features observed from satellites. Deep-Sea Research. Part I. Oceanogr. Res. Pap. 31:1085-1099.

Lee, Y.C. and Liu, H.C. (1992) Age determination by vertebra reading in Indian albacore Thunnus alalunga bonnaterre. J. Fish. Soc. Taiwan 19:89-102.

Nakamura, H. (1969) Tuna Distribution and Migration. London: The Whitefriairs Press Ltd, $76 \mathrm{pp}$.

Ramos, A.G., Santiago, J., Sangra, P. and Canton, M. (1996) An application of satellite-derived sea surface temperature data to the skipjack (Katsuwonus pelamis Linnaeus, 1758) and albacore tuna (Thunnus alalunga Bonaterre, 1788) fisheries in the north-east Atlantic. Int. J. Rem. Sens. 17:749-759.

Saito, S., Ishii, K. and Yoneta, K. (1970) Swimming depths of large sized albacore in the South Pacific Ocean-I. Fishing of albacore by newly designed vertical longline. Bull. Jpn Soc. Sci. Fish. 36:578-584.

Shiohama, T. (1985) Overall fishing intensity and length composition of albacore caught by long line fishery in the Indian Ocean, 1952-1982. IPTP TWS/85/22 91-109.

Stretta, J.M. (1991) Forecasting models for tuna fishery with aerospatial remote sensing. Int. J. Rem. Sens. 12:771-779.

Suda, A. (1974) Recent status of resources of tuna exploited by longline fishery in the Indian Ocean. Bull. Far Seas Fish. Res. Lab. 10:27-62. 
Sund, P.N., Blackburn, M. and Williams, F. (1981) Tunas and their environment in the Pacific Ocean: a review. Oceanogr. Mar. Biol. Ann. Rev. 19:443-512.

Ueyanagi, S. (1969) Observations on the distribution of tuna larva in the Indo-Pacific Ocean with emphasis on the delineation of spawning areas of albacore, Thunnus alalunga. Bull. Far Seas Fish. Res. Lab. 2:177-219.

Wang, S.H. (2001) An application of fuzzy synthesis theory on the assessment of albacore stock in the Indian Ocean. $\mathrm{PhD}$ Dissertation, National Taiwan University (in Chinese, English abstract).

Wang, S.H., Hsu, C.C. and Liu, H.C. (2001) Using fuzzy synthesis approach to extract fishing efforts directed on albacore for Taiwanese longline fleets in the Indian Ocean. J. Fish. Soc. Taiwan 28:105-118.
Wu, C.L. and Kuo, C.L. (1993) Maturity and fecundity of albacore, Thunnus alalunga (Bonnaterre), from the Indian Ocean. J. Fish. Soc. Taiwan 20:135-151.

Wyrtki, K. (1973) Physical oceanography of the Indian Ocean. In: The Biology of the Indian Ocean. B. Zeitzschel (ed.). Berlin, New York: Spring-Verlag, pp. 18-36.

Yamanaka, H. (1956) vertical structure of the Ocean in relevant to Fishing conditions for albacore adjacent to $10^{\circ} \mathrm{S}$ in the Western South Pacific. Bull. Jpn Soc. Sci. Fish. 21:11871193.

Yoneta K. and Saito, S. (1973) Studies on the large-sized albacore and its vertical distribution in the Western South Pacific Ocean. Bull. Jpn Soc. Sci. Fish. 39:617-624. 